\title{
Productivity Improvement through the Systematic Application of Facility Layout Planning in a Small- Scale Woodcraft Manufacturing Industry
}

\author{
Ariel G. Cabildo, Ayezza Marie S. Figueroa, Emmanuel John V. Angeles, Jaypee B. Pajarillaga, Lorinda
}

E. Pascual

\begin{abstract}
: the study's goal is to help increase the productivity of the company by introducing a systematic layout plan in production department of VENRON Wood Home Craft Manufacturing Industry. Systematic Layout Planning application is the focus of the study to help improve productivity in the company an evaluation and workflow analysis to the current layout was used to identify the problems the company is experiencing using a fishbone diagram to represent it. A conceptual framework using IPO model was divided into several inputs and processes needed in proposing alternative layout. Process time study and layout planning tools such as from-to chart, activity relationship diagram, space requirement and block diagram will be used to develop and achieve alternative layouts The study resulted to a decrease in travel time and distance improving the productivity resulting to more production in a given time. A basic workplace safety manual for the company has been made to help the company and the workers gain knowledge and how, when and why should safety be in their practice. Costbenefit analysis using comparative analysis will be calculated in the company's result to production per day to determine on how does the proposed layout could affect and have benefit to the company. The result of the study is that proposing a new layout could really improve the production of the company producing more units per day compared to the current one.
\end{abstract}

Keywords: Wood Home Craft Manufacturing Industry, Facility Layout Planning, Workplace Safety, Manual

\section{INTRODUCTION}

Today, many Filipinos are engaged in handicraft businesses. Handicraft-making has become a means of livelihood for them, especially now that many handicraft owners are exporting their products to Japan, United States, Canada, Australia, Hong Kong, Singapore, and other countries around the world [1].

Revised Manuscript Received on March 17, 2020.

* Correspondence Author

Ariel G. Cabildo*, Graduate School Department, Nueva Ecija University of Science and Technology, Cabanatuan, Nueva Ecija, Philippines. Email: arielgonzalescabildo@gmail.com@gmail.com

Ayezza Marie S. Figueroa., School of Engineering and Architecture, Holy Angel University, Angeles City, Pampanga, Philippines Email: ayezzamarief@gmail.com@gmail.com

Emmanuel John V. Angeles., Graduate School Department, Nueva Ecija University of Science and Technology, Cabanatuan, Nueva Ecija, Philippines. Email emsangeles29@gmail.com

Jaypee B. Pajarillaga., School of Engineering and Architecture, Holy Angel University, Angeles City, Pampanga, Philippines Email: jpajarillaga1975@gmail.com

Lorinda E. Pascual., Graduate School Department, Nueva Ecija University of Science and Technology, Cabanatuan, Nueva Ecija, Philippines. Email: lorindapascual15@gmail.com

(C) The Authors. Published by Blue Eyes Intelligence Engineering and Sciences Publication (BEIESP). This is an open access article under the CC BY-NC-ND license (http://creativecommons.org/licenses/by-nc-nd/4.0/)
Handicraft industry is important because it enhances creativity and provides employment to those who are in need. Handicrafts are a form of industry and products that are, for the greater part made by hand. They are usually produced with low initial capital investment from materials available mostly within the producing country.

According to United Nations Educational, Scientific and Cultural Organization/ Information Technology Community (UNESCO /ITC) International Symposium on "Crafts and the International Market: Trade and Customs Codification", Manila, Philippines, October 1997: Handicrafts can be defined as products which are produced either completely by hand or with the help of tools. Mechanical tools may be used as long as the direct manual contribution of the artisan remains the most substantial component of the finished product. Handicrafts are made from raw materials and can be produced in unlimited numbers. Such products can be utilitarian, aesthetic, artistic, creative, culturally attached, decorative, functional, traditional, religiously and socially symbolic and significant [2].

Thus handicraft requires a lot of skill and hard work that goes into every piece of handicraft. Each handicraft is a masterpiece in its own right. Throughout the Philippines, the commercial middle class is gradually expanding on the level of provincial capital, municipal town, and village. The entrepreneurs who form this class take part in the continuing commercialization of the rural and urban economies, and profit from it. A little-known category in this rising entrepreneurial class consists of traders and manufacturing entrepreneurs in the country's expanding crafts.' Important manufacturing industries based on household or workshop production, and geared to the domestic or export market, are concentrated in several Philippine provinces.

The rapid rise of export crafts was due to an increase in Western demand for tropical gift ware, the spread of international subcontracting, and the export oriented industrialization policy initiated by the Marcos administration in the 1970s. An important precondition for this expansion was that small production units in villages and towns were still viable for the manufacture of a range of consumer goods. It is this feature that accounted for the ramified networks of provincial traders and subcontracting entrepreneurs that link small producers to wider markets. Production usually takes place in rural areas or small towns because of a local supply of raw materials and/or of cheap, underemployed labor. Production units remain small because there is little financial incentive, or opportunity, for entrepreneurs to mechanize. With this arising competition within the handicraft industry, production strategies and product quality should be within the parameter of its demand [3].

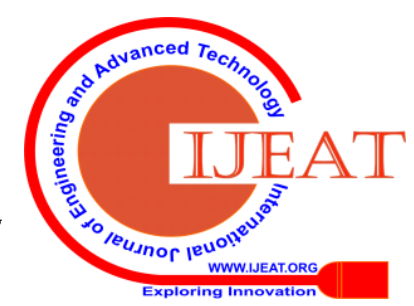




\section{Productivity Improvement through the Systematic Application of Facility Layout Planning in a Small-Scale Woodcraft Manufacturing Industry}

In this study, the case company is a small scale wood handicraft company named VENRON Home craft. It is one of the leading suppliers of wood carved products such as plates, bowls, cutting boards, salad servers etc. In U.S., Japan, Mexico, South Korea and Hawaii through their contractors which are Durus, Starwood, Sunwood and Jarah Homeraft. It was founded by Mr. Jaime T. Quiros in 1982. He was the father of the current owner and operation manager Mr. Ronald T. Quiros. The company started on specializing wood carving for their product last July 31, 2014.Products are made base to the purchase order of the contractor company and raw materials were ordered in a just in time basis. Customers of the contractor mostly order products like chopping boards, round plates, square plates, salad servers and bowls all made out of acacia woods. The company has 34 workers inside its production that is located at Purok 1, Brgy. Calantas, Floridablanca Pampanga. The workers were divided on each process were 5 workers are for cutting, 3 for carving, 2 for drying, 5 for sanding, 5 for quality control and 12 are for finishing and packing and 2 additional workers are for Material Handling. Workers have a minimum of 8 labor hours and could take an overtime work that is up to 12 hours. Machines are used in some processes of the company, such as Bandsaw Machine, Torno and Lathe Machine, Planing Machine and Sanding Machine.

Production is a scientific process which involves transformation of raw material (input) into desired product or service (output) by adding economic value [4]

Facility planning is concerned with the design, layout, and accommodation of people, machines and activities of a system or enterprise within a physical spatial environment. Facility planning is very important in a manufacturing process due to their effect in achieving an efficient product flow. It is estimated that between $20 \%-50 \%$ of the total costs in manufacturing is related to material handling. Plant layout planning aims to have a more effective work flow at the facility, allowing workers and equipment being more productive [5]

One of the main purposes of this is to find the most effective facility arrangement and minimize material handling [6]. An emerging consensus that existing layout configurations do not meet the needs of manufacturing companies to which there is a need for a new generation of standardized work that is more flexible and modular. This action could be conducted under existing resources such as employees, machines and other facilities. Work Standardization has become a fundamental basis of today's industrial plants which can influence parts of work efficiency [7]

A fishbone diagram below shows a representation of the collected data based from the observations, surveys and interviews being conducted in the company that will discuss the problem that was being identified in the company.

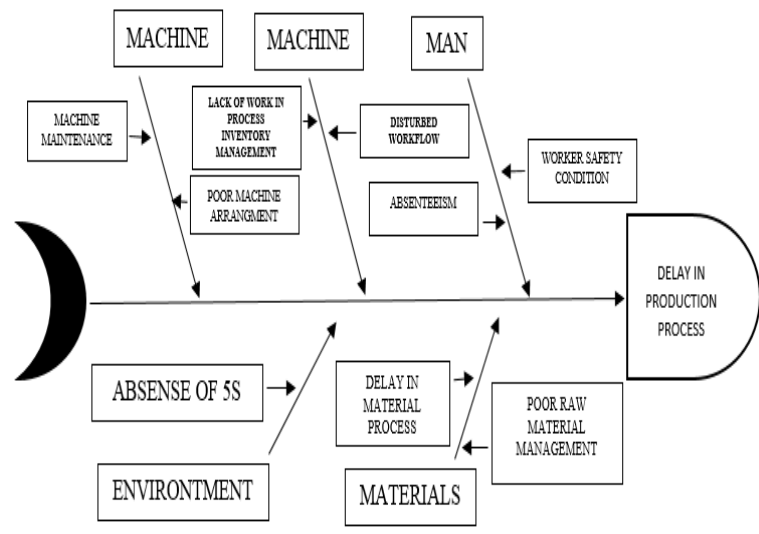

Figure 1: Fishbone Diagram

Table 1: Survey Checklist Result

\begin{tabular}{|c|c|c|}
\hline MAN & YES & NO \\
\hline Absenteeism & $78.95 \%$ & $55.88 \%$ \\
\hline Lack of proper training & $13.33 \%$ & $88.24 \%$ \\
\hline Over Fatigue & $54.55 \%$ & $64.71 \%$ \\
\hline MACHINE & YES & $\mathrm{NO}$ \\
\hline Poor Machine Arrangement & $58.82 \%$ & $41.18 \%$ \\
\hline Machine maintenance & $29.41 \%$ & $70.59 \%$ \\
\hline Safety & $55.88 \%$ & $44.12 \%$ \\
\hline METHOD & YES & $\mathrm{NO}$ \\
\hline Production Flow & $61.76 \%$ & $38.24 \%$ \\
\hline Travel Flow & $55.88 \%$ & $44.12 \%$ \\
\hline Standard process of the production & $26.47 \%$ & $73.53 \%$ \\
\hline MATERIAL & YES & $\mathrm{NO}$ \\
\hline Proper storage of materials & $58.82 \%$ & $41.18 \%$ \\
\hline Material supply & $70.00 \%$ & $58.82 \%$ \\
\hline ENVIRONMENT & YES & NO \\
\hline Facility Layout & $55.88 \%$ & $44.12 \%$ \\
\hline Safety & $61.76 \%$ & $38.24 \%$ \\
\hline Disturbed Workflow & $64.71 \%$ & $35.29 \%$ \\
\hline Cleanliness & $55.88 \%$ & $44.12 \%$ \\
\hline Orderliness & $55.88 \%$ & $44.12 \%$ \\
\hline
\end{tabular}

In determining the factors that could affect the productivity a checklist survey was being conducted to the workers of the company. As shown above, the results that are above 50 percent has a high effect in the company's productivity.

An initial assessment of the workplace area, process and production flow was being conducted to identify the factors that are affecting any of the company's system. The problem that is being encountered is delay in the production process due to several factors that is involved in it. These factors are being showed in the body of the fishbone diagram. After the diagram is being assessed areas of improvement are being chosen. Environment, man and method were the chosen field to conduct a primary study to solve the problem. During the observation the environment of the production

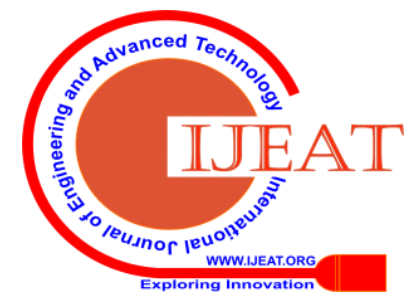


system lacks of cleanliness and orderliness during the work in process flow.

It has a poor facility layout design that blocks the continuous flow of the production. And workers were prone to accidents based on observed hazards.

The general objective of this study is to assess the existing facility layout of the company to improve productivity in the production process by achieving the following specific objective:

- To introduce Systematic Layout Plan for the company

- To improve company's productivity and process flow through travel time and distance reduction

- $\quad$ To recommend a Basic Workplace Safety Manual to increase safety measures and knowledge of the workers in the company.

\section{METHODOLOGY}

\section{A. Data Collection and Instrument}

An Input-Process-Output (IPO) model was made to define the requirement in conducting the study, processing of the requirements, and the final output.

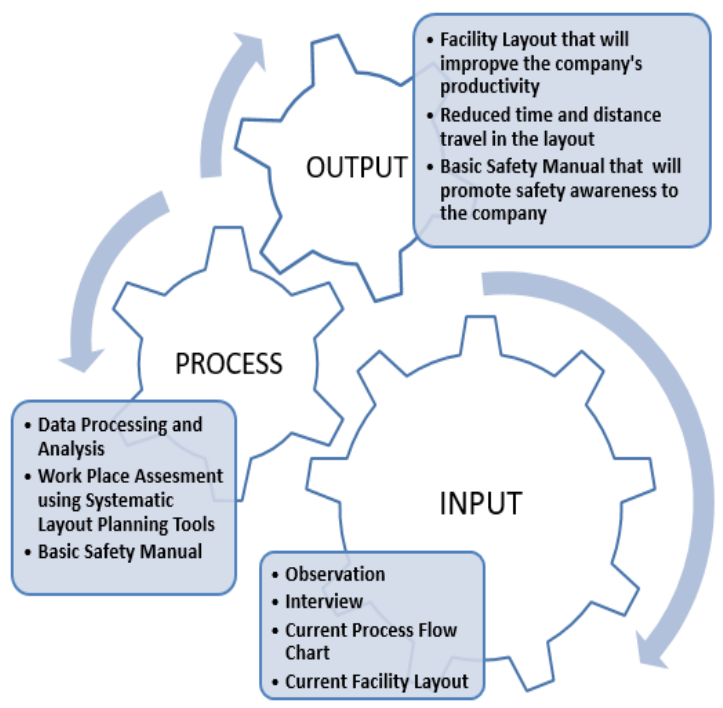

Figure 2: Conceptual Framework of the Study

Data should be gathered first to identify the target of the study. To acquire data Observation, Interview and Analysis of the work area was being conducted. Implementation will be followed after the data gathering. Process implementation will be then followed by the result of the study.

The study is for the improvement of VENRON Home craft in their production process through current layout assessment and improved workplace area for improved production process management. The study is mainly for the company that workers, production and management will benefit to its result and implementation. The company aims to increase the productivity of the company by with an application of a new systematic layout plan. The purpose of the study for the student is to be able to apply and practice the industrial engineering tools and concepts being acquired in the school.

Scope of the study will be centered and limited in the production area of the company for the proposed systematic layout plan. Basic workplace safety manual will also be prepared for the company's awareness for safety. The study aims to increase productivity within the company's production area.

Observation and interviews were the initial methods being used to gather data. Observation to company layout design and process flow chart is being done to have an initial data to assess the company's situation to determine where to conduct a study. Interview to the company owner and operation manager was conducted to have an insight to some of the problem the company is encountering.

A descriptive research design was used to acquire this relevant and important information. A Systematic Layout Planning was used to assess current facility layout of the company and introduce new alternative layouts that will optimize the company's production layout

The subject of this study is the management and workers of the company that will benefit to the study. They will be the basis in implementing the study that will test and evaluate the further result

The primary data were being gathered through interviews with the owner and workers within the company. The secondary data were from Journals, Articles and Books that are related and will be related to the study

The following are the procedures needed to gather important information to support the proposed stud:

Observation is the initial data collection process that will acquire basic primary data being gathered.

Interview will be a secondary data that will be gathered from the people involved in the company.

Work area assessment through observation was being performed to assess the need in proposing a layout plan, 5s Housekeeping, waste management and a layout for workplace safety for the company.

\section{B. Data Processing and Analysis}

A time study was conducted in line with the work measurement to find out how long should the proposed system will it takes to complete the process in the case company. This method required direct observation using a stopwatch. It was also to analyze the more specific process through which qualified workers in an effort to identify the most efficient in terms of time. Westinghouse system of rating performance rating factor was used to modify the pace of the worker such as personal factors, shift adjustments, fatigue, and unavoidable delays which are consider on determining standard time

Formula for normal time:

$$
N T=O T x P R
$$

Where:

$$
\begin{aligned}
& \text { NT }=\text { Normal time } \\
& \text { OT }=\text { Observed time }
\end{aligned}
$$

\section{Systematic Layout Planning}

Layout Planning will be used to find a solution in improving the current layout to apply the Industrial Engineering tools to be practiced and implemented.

\section{From-To Chart}

From-to chart provided information concerning the number of material handling trips within the production area.

\section{Activity Relationship Chart}

Published By:

Blue Eyes Intelligence Engineering

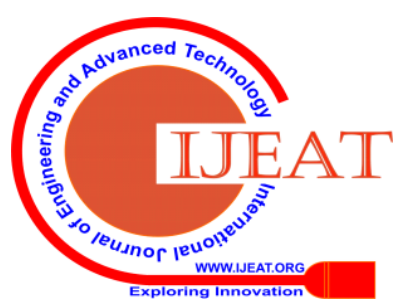

\& Sciences Publication 
Activity relationship chart measured the closeness rating between sections in the production area.

\section{Space Requirement}

Determination of the amount of space available in the facility and space required for workstations which includes personnel, materials and equipment.

Cost Benefit Analysis

Cost benefit analysis was used for the evaluation of the time saved, cost saved, cost saved per day and cost saved per month upon implementing

\section{RESULTS \& DISCUSSION}

\section{A. General Process Flow Chart of the Company's production}

The case company has 3 departments; the processing department, finishing department and packaging department. Figure 3 shows the company's current exiting layout. Based on the observation the production area is the most needed area that is to be assessed. The production department is located at the back of the company layout and it includes most of the production process of the product and the wood raw materials.

The General Process Flow Chart of the Company's production was shown on Figure 4 to give a clear flow on how the product flows in the whole operation. The Material Flow of the product and the frequency of the flow was being shown on Table 2.

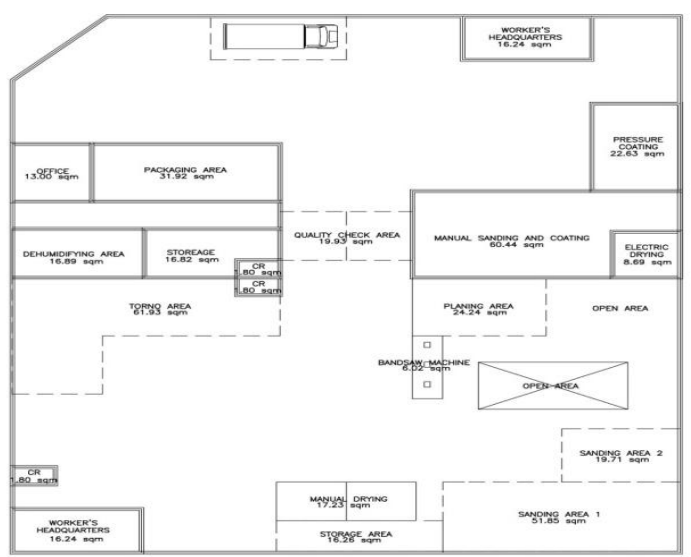

Figure 3: Company's Current Layout

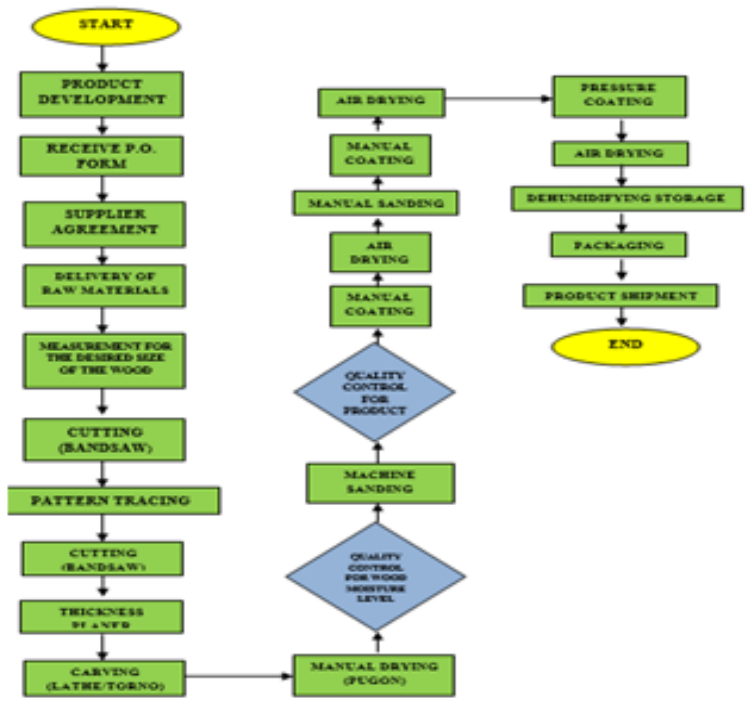

Figure 4: Company's General Process Flowchart

Table 2: Material Flow in Current Layout

\begin{tabular}{|c|c|c|c|c|}
\hline No & Flow & Time (min) & Frequency & Total \\
\hline 1 & $\begin{array}{c}\text { Raw Material Area- } \\
\text { Cutting Area }\end{array}$ & 0.080 & 20 & 1.635 \\
\hline 2 & $\begin{array}{c}\text { Cutting Area- Tracing } \\
\text { Area }\end{array}$ & 0.103 & 8 & 0.843 \\
\hline 3 & $\begin{array}{c}\text { Tracing Area- Cutting } \\
\text { Area }\end{array}$ & 0.103 & 8 & 0.843 \\
\hline 4 & $\begin{array}{l}\text { Cutting Area- Planning } \\
\text { Area }\end{array}$ & 0.283 & 8 & 2.312 \\
\hline 5 & $\begin{array}{c}\text { Planning Area- Carving } \\
\text { Area }\end{array}$ & 0.637 & 8 & 5.199 \\
\hline 6 & $\begin{array}{l}\text { Carving Area- Manual } \\
\text { Drying }\end{array}$ & 0.598 & 8 & 4.878 \\
\hline 7 & $\begin{array}{l}\text { Manual Drying- Machine } \\
\text { Sanding }\end{array}$ & 0.421 & 4 & 1.716 \\
\hline 8 & $\begin{array}{l}\text { Machine Sanding- Quality } \\
\text { Check Area }\end{array}$ & 1.830 & 8 & 14.930 \\
\hline 9 & $\begin{array}{l}\text { Quality Check Area- } \\
\text { Manual Coating Area } 1\end{array}$ & 0.216 & 14 & 2.940 \\
\hline 10 & $\begin{array}{c}\text { Manual Coating Area 1- } \\
\text { Manual Sanding Area }\end{array}$ & 0.372 & 14 & 5.057 \\
\hline 11 & $\begin{array}{l}\text { Manual Sanding Area- } \\
\text { Manual Coating Area } 2\end{array}$ & 0.265 & 14 & 3.606 \\
\hline 12 & $\begin{array}{c}\text { Manual Coating Area 2- } \\
\text { Logo Stamping Area }\end{array}$ & 0.220 & 14 & 2.994 \\
\hline 13 & $\begin{array}{l}\text { Logo Stamping Area - } \\
\text { Pressure Coating Area }\end{array}$ & 0.423 & 14 & 5.746 \\
\hline 14 & $\begin{array}{l}\text { Pressure Coating Area- } \\
\text { Dehumidifying Storage } \\
\text { Room }\end{array}$ & 1.313 & 14 & 17.852 \\
\hline \multirow[t]{2}{*}{15} & $\begin{array}{l}\text { Dehumidifying Storage } \\
\text { Room- Packaging Area }\end{array}$ & 0.172 & 14 & 2.337 \\
\hline & & 7.036 & & 72.890 \\
\hline
\end{tabular}

\section{B. Spaghetti diagram approach}

Spaghetti diagram shows the movement of materials using a continuous flow line tracing the path of an item through processes shown in Figure 5. The thickness of lines shows the frequency of travel flow in the process. The legend shows the observation in the following colors per process to process

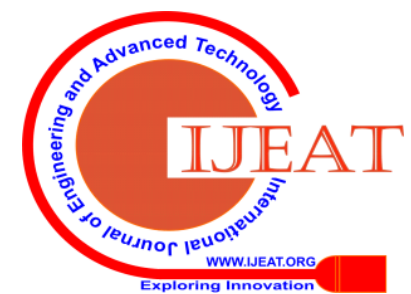




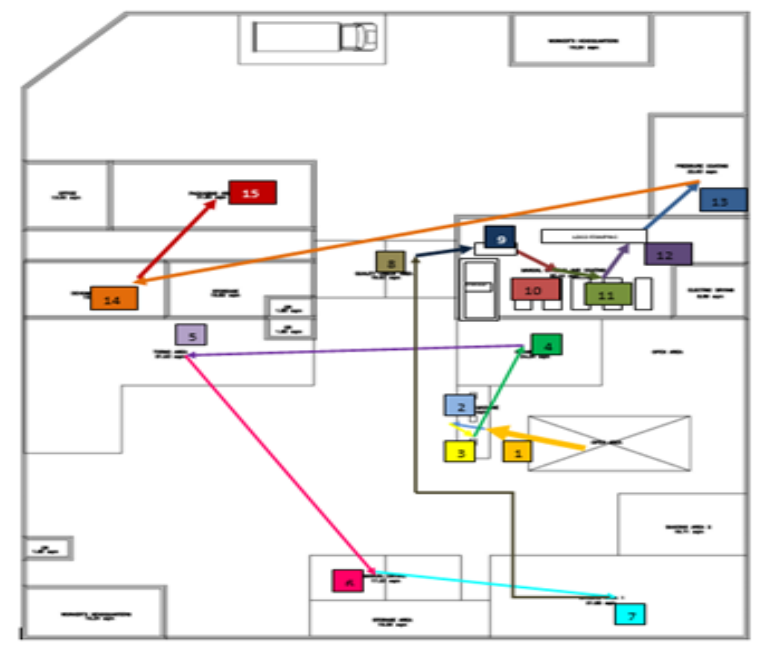

Figure 5: Spaghetti Diagram for Company's Current Existing Layout

Legend:

\begin{tabular}{|c|c|}
\hline Observation 1 & \\
\hline Observation 2 & \\
\hline Observation 3 & \\
\hline Observation 4 & \\
\hline Observation 5 & \\
\hline Observation 6 & \\
\hline Observation 7 & \\
\hline Observation 8 & \\
\hline Observation 9 & \\
\hline Observation 10 & \\
\hline Observation 11 & \\
\hline Observation 12 & \\
\hline Observation 13 & \\
\hline Observation14 & \\
\hline Observation 15 & \\
\hline
\end{tabular}

Figure 6: Spaghetti Diagram Legend

Abbreviations were being used in order to easily recognize the department used in constructing from-to chart. Abbreviations of departments were shown in Table 3

\begin{tabular}{|c|c|c|}
\hline $\begin{array}{c}\text { Allowance } \\
(\text { sqm })\end{array}$ & $\begin{array}{c}\text { Total } \\
\text { Space per } \\
\text { Machine } \\
\text { (sqm) }\end{array}$ & $\begin{array}{c}\text { Number of } \\
\text { Machine/Equipment }\end{array}$ \\
\hline $150 \%$ & 37.845 & - \\
\hline $150 \%$ & - & 3 \\
\hline $150 \%$ & 16.16 & 2 \\
\hline $150 \%$ & 16.12 & 1 \\
\hline $150 \%$ & 17.81 & - \\
\hline $150 \%$ & 16.14 & 9 \\
\hline $150 \%$ & 39.35 & - \\
\hline $150 \%$ & 14.58 & 2 \\
\hline
\end{tabular}

Table5. From-To Distance Table of Current Existing Layout

\begin{tabular}{|c|c|c|c|c|c|}
\hline Process Type & Length (m) & Width (m) & Area (sqm) & $\begin{array}{c}\text { Operator } \\
\text { Space } \\
\text { (sqm) }\end{array}$ & Subtotal \\
\hline
\end{tabular}

Published By:

Blue Eyes Intelligence Engineering \& Sciences Publication

(c) Copyriaht: All riahts reserved.

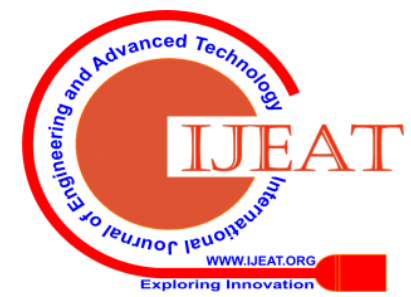


Productivity Improvement through the Systematic Application of Facility Layout Planning in a Small-Scale Woodcraft Manufacturing Industry

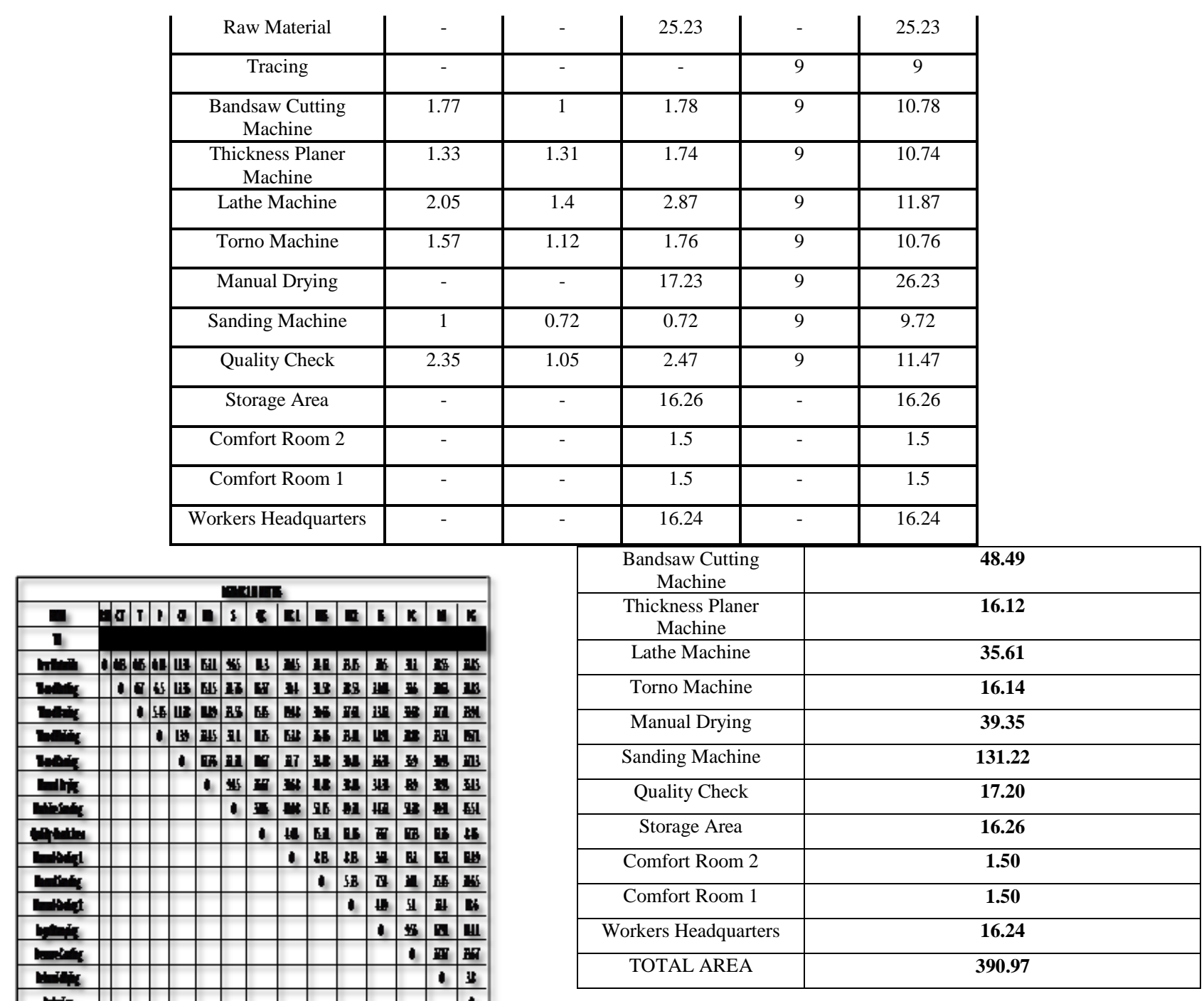

Conducting a From-To Chart the total distance and time travelled of the current existing layout was being determined. Following the production flow of RM-CT-TCT-P-CV-MD-S-QC-MC1-MLS-MC2-LS-PC-DH-PG the total travel distance is $142.15 \mathrm{~m}$ and the total travel time is $6.92 \mathrm{~min}$

Space Requirement is being computed to determine the space to be considered and the availability of it by understanding the flow between machines and the interaction between the facilities we can determine the space necessary for the work area.

To calculate the extra space in the work area the workstation, auxiliary equipment, operator space, incoming material and work-in- process space and it will be added to other separate quantities to determine the total space needed for each workstation.

Typically, $150 \%$ of space allowance is needed for the extra space (Sunderesh Heragu, 1997)

The summary of Total Space required for each production area was being shown on Table 7 . The calculated total area requirement for the production department is $390.97 \mathrm{sqm}$.

Table 7: Total Space Requirement for Each Production Area

\begin{tabular}{|c|c|}
\hline Process Type & $\begin{array}{c}\text { Total Space Requirement for Each Production } \\
\text { Area (sqm) }\end{array}$ \\
\hline Raw Material & $\mathbf{3 7 . 8 5}$ \\
\hline Tracing & $\mathbf{1 3 . 5 0}$ \\
\hline
\end{tabular}

\section{Space Comparison of Current and Required}

A comparison to the current and requireed area for each process was being shown on Table 8 . This proves that some of the work area were overspaced or underspaced.

Table 8: Space Comparison of Current and Required

\begin{tabular}{|c|c|c|}
\hline Process Type & Current Space & $\begin{array}{c}\text { Required } \\
\text { Space }\end{array}$ \\
\hline Raw Material & Unidentified & 37.845 \\
\hline Tracing & 6.02 & 13.5 \\
\cline { 3 - 3 } Cutting Machine & & 48.49 \\
\hline Thickness Planer Machine & 24.24 & 16.12 \\
\hline Carving Machine & 61.93 & 51.75 \\
\hline Manual Drying & 17.23 & 39.345 \\
\hline Sanding Machine & 51.85 & 131.22 \\
\hline Quality Check & 19.93 & 17.20125 \\
\hline
\end{tabular}

Standard Time to each process was being compute as shown on Table 9. The particular small round wooden plate product would take 112.04 mins per piece to be fully produced.

Table 9: Standard Time Table of Process

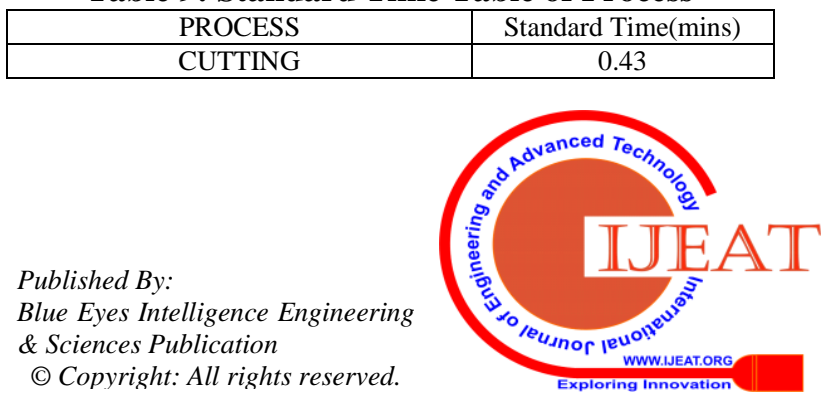




\begin{tabular}{|c|c|}
\hline PATTERN TRACING & 0.11 \\
\hline CUTTING & 0.49 \\
\hline THICKNESS PLANER & 0.38 \\
\hline LATE/TORNO MACHINE & 2.09 \\
\hline MANUAL DRYING & 0.30 \\
\hline QUALITY CHECK & 1.25 \\
\hline MACHINE SANDING & 1.21 \\
\hline QUALITY CHECK & 1.25 \\
\hline MANUAL COATING 1 & 1.40 \\
\hline AIR DRYING & 0 \\
\hline MANUAL SANDING & 1.41 \\
\hline MANUAL COATING 2 & 1.24 \\
\hline AIR DRYING & 0 \\
\hline LOGOSTAMPING & 0.24 \\
\hline PRESSURE COATING & 0.31 \\
\hline AIR DRYING & 0 \\
\hline TOTAL & 12.85 \\
\hline
\end{tabular}

Table10: Production Capacity of Each Process per Day

\begin{tabular}{|c|r|}
\hline PROCESS & Capacity \\
\hline CUTTING & $1,058.15$ \\
\hline PATTERN TRACING & $4,018.82$ \\
\hline CUTTING & 911.74 \\
\hline THICKNESS PLANER & $1,176.19$ \\
\hline LATE/TORNO MACHINE & 215.62 \\
\hline MANUAL DRYING & $1,488.10$ \\
\hline QUALITY CHECK & 360.31 \\
\hline MACHINE SANDING & 373.07 \\
\hline QUALITY CHECK & 360.31 \\
\hline MANUAL COATING 1 & 321.38 \\
\hline AIR DRYING & $1,800.00$ \\
\hline MANUAL SANDING & 319.75 \\
\hline MANUAL COATING 2 & 363.95 \\
\hline AIR DRYING & $1,800.00$ \\
\hline LOGOSTAMPING & $1,877.40$ \\
\hline PRESSURE COATING & $1,455.91$ \\
\hline AIR DRYING & $1,800.00$ \\
\hline
\end{tabular}

A computed production capacity for each process was shown at Table 10. Capacity was used to determine the limit of the production for the specific area. The Production which is the lowest capacity will be declared as the overall production capacity.

To define the adjacency and closeness of the process and machines a relationship diagram was being made as seen below on Figure 7. The specific letter codes and numbers were being used to assign the relationship.

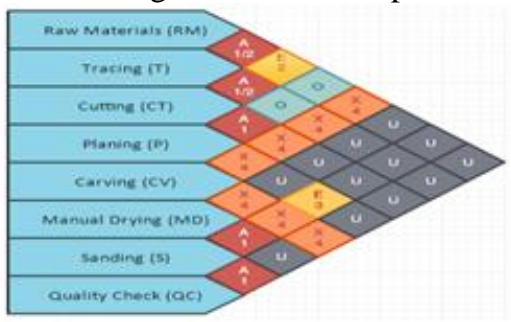

Figure 7: Production Department Activity Relationship Diagram

A summarize work sheet table was being shown on Table 11 to be used in implementing a new proposed layout for the company to help in the systematic flow of the process.

Table 11: Relationship Diagram Worksheet Summary PROCESSING DEPARTMENT

\begin{tabular}{|c|c|c|c|c|c|c|}
\hline $\begin{array}{c}\text { Relati } \\
\text { onship }\end{array}$ & RM & P & CV & MD & S & QC \\
\hline
\end{tabular}

\begin{tabular}{|c|c|c|c|c|c|c|}
\hline A & T & CT & - & S & $\begin{array}{c}\text { MD, } \\
\text { QC }\end{array}$ & S \\
\hline E & CT & S & - & - & P & - \\
\hline I & - & - & - & - & - & - \\
\hline O & $\mathbf{P}$ & $\begin{array}{c}\text { T,R } \\
\text { M }\end{array}$ & - & - & - & - \\
\hline U & $\begin{array}{c}\text { MD, } \\
\text { S,Q } \\
\mathbf{C}\end{array}$ & $\begin{array}{c}\text { MD } \\
\text {,QC }\end{array}$ & - & $\begin{array}{c}\text { P,CT,T, } \\
\text { RM,QC }\end{array}$ & $\begin{array}{c}\text { CT, } \\
\text { T,R } \\
\text { M }\end{array}$ & $\begin{array}{c}\text { S,MD,P, } \\
\text { CT,T,RM }\end{array}$ \\
\hline X & $\mathbf{C V}$ & $\mathbf{C V}$ & $\begin{array}{c}\text { P,CT,RM,T } \\
\text {,MD,S,QC }\end{array}$ & CV & $\mathbf{C V}$ & $\mathbf{C V}$ \\
\hline
\end{tabular}

To represent and conduct a block diagram, areas were being rounded off and divided into 2 to produce a lower number in building the blocks. See appendix _ to show the computation. The summary of the required block was being shown on Table 12.

Table 12: Block Distribution Summary

\begin{tabular}{|c|c|c|}
\hline Code & Process Type & $\begin{array}{c}\text { Number of } \\
\text { Blocks }\end{array}$ \\
\hline RM & Raw Material & 19 \\
\hline T & Tracing & 7 \\
\hline CT & $\begin{array}{c}\text { Bandsaw Cutting } \\
\text { Machine }\end{array}$ & 25 \\
\hline P & $\begin{array}{c}\text { Thickness Planer } \\
\text { Machine }\end{array}$ & 9 \\
\hline CV & Lathe Machine & 18 \\
\cline { 2 - 3 } & Torno Machine & 9 \\
\hline MD & Manual Drying & 20 \\
\hline S & Sanding Machine & 66 \\
\hline QC & Quality Check & 9 \\
\hline SA & Storage Area & 9 \\
\hline CR1 & Comfort Room 2 & 1 \\
\hline CR2 & Comfort Room 1 & 1 \\
\hline WH & Workers Headquarters & 9 \\
\hline
\end{tabular}

\section{Proposed Layout 1 for the Company}

Following the required areas for each process, the researcher proposed four alternative layouts for the company. Layouts were being based on the activity relationship diagram and the space requirements needed for each process to develop a systematic layout plan. The proposed layouts were being shown on Figure 8, 10 and Figure 12.

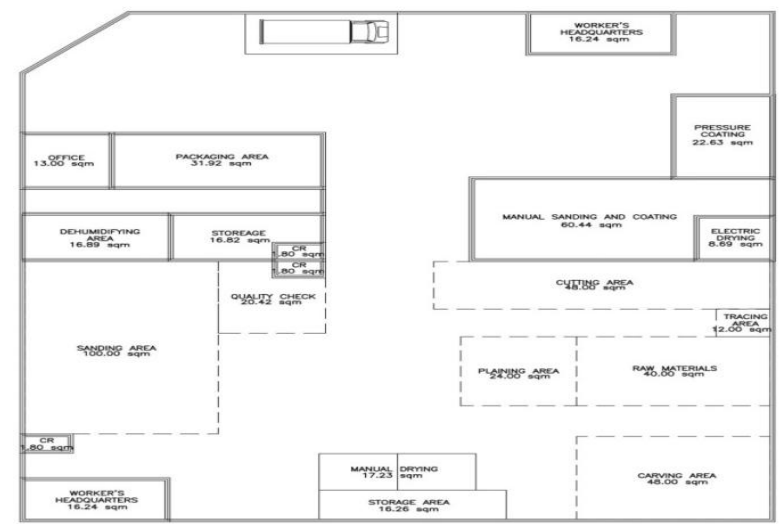

Figure 8: First Proposed Layout for the Company

Published By:

Blue Eyes Intelligence Engineering \& Sciences Publication

(C) Copyriaht: All riahts reserved.

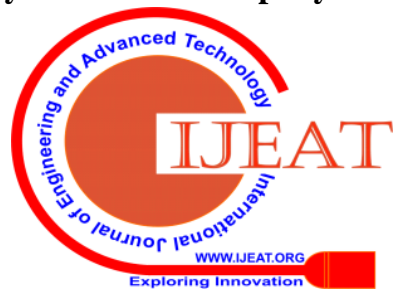


Productivity Improvement through the Systematic Application of Facility Layout Planning in a Small-Scale Woodcraft Manufacturing Industry

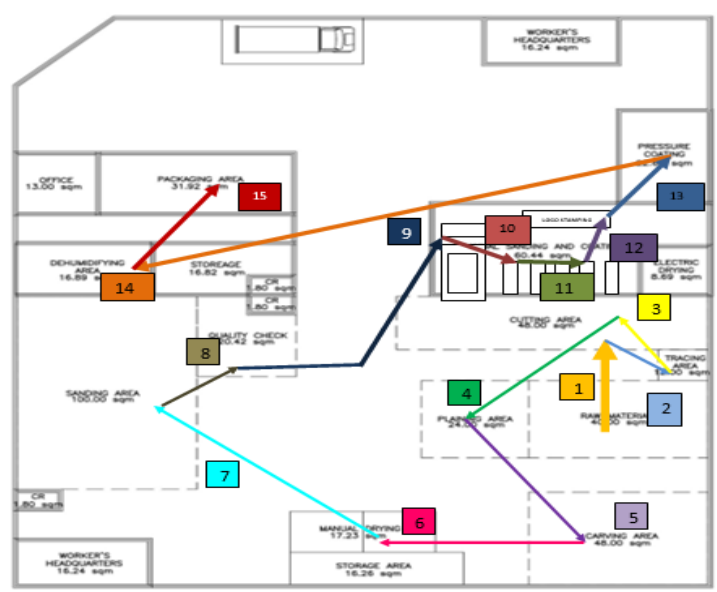

Figure 9. Spaghetti Diagram for the First Proposed Layout for the Company

Table 13: From-To Distance Table of First Propose Layout

\begin{tabular}{|c|c|c|c|c|c|c|c|c|c|c|c|c|c|c|c|c|}
\hline \multicolumn{17}{|c|}{ |l } \\
\hline \multicolumn{17}{|c|}{ (5) } \\
\hline ש & 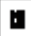 & d & \begin{tabular}{|l|}
$\mathbf{T}$ \\
$\mid$
\end{tabular} & & & d & | & 5 & 6 & |r| & E & $\mathbf{n}$ & I & $\mid \mathbf{r}$ & & $\mathbf{K}$ \\
\hline I & & & & & & & & & & & & & & & & \\
\hline trit & 1 & 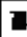 & 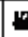 & & & 8 & 1 & 3 & 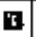 & 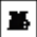 & in & \begin{tabular}{|l|}
35 \\
\end{tabular} & $\mathbf{x}$ & A & & $\pi$ \\
\hline -7t & & 1 & ix & & & 5 & 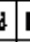 & 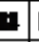 & in & ㅍ & $\mathbf{s}$ & $\mathbf{0}$ & $\mathbf{u}$ & II & & $\mathbf{H}$ \\
\hline 15 & & & 1 & 1 & & 1 & 8 & ty & $\mathbf{s}$ & $\mathbf{n}$ & 政 & in & $\mathbf{3}$ & $\mathbf{x}$ & & $\pi$ \\
\hline Dint & & & & ( & & \$ & 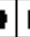 & c & v. & $\mathbf{E}$ & $=$ & ㅂ & Ei & $\mathbf{n}$ & & 1 \\
\hline wit & & & & & & 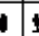 & 1 & $\pi$ & v & $\pi$ & III & 고 & $\mathbf{n}$ & 3 & & $\mathrm{IE}$ \\
\hline -11 & & & & & & 7 & 1 & 可 & 䤃 & in & in: & $\mathbf{3}$ & $\mathbf{D}$ & AS & & 7 \\
\hline | & & & & & & & & 1 & $\mathbf{4}$ & 든 & 95 & 1 & a & ax & & 59 \\
\hline (1) & & & & & & & & & 1 & 마 & 政 & $\boldsymbol{m}$ & E & $\mathbf{2 3}$ & & 19 \\
\hline - & & & & & & & & & & 1 & B日 & 4 & in & 的 & & $\mathrm{u}$ \\
\hline this & & & & & & & & & & & 1 & a & 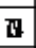 & $\mathbf{n}$ & & 14 \\
\hline Lent & & & & & & & & & & & & 1 & 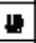 & SI & & 5 \\
\hline 7 & & & & & & & & & & & & & 1 & $\mathbf{4 5}$ & & 11 \\
\hline-1 & & & & & & & & & & & & & & 1 & & 8 \\
\hline 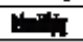 & & & & & & & & & & & & & & & & II \\
\hline ע & & & & & & & & & & & & & & & & 1 \\
\hline
\end{tabular}

Table 14: From-To Time Table of First Propose Layout

\begin{tabular}{|c|c|c|c|c|c|c|c|c|c|c|c|c|c|c|c|}
\hline \multicolumn{16}{|c|}{ and } \\
\hline \multicolumn{16}{|c|}{ Ifis } \\
\hline$\square$ & 1 & d & I & 1 & a & D & 1 & 6 & 1 & E & $\mathbf{a}$ & I & 【 & II & 5 \\
\hline 】 & & & & & & & & & & & & & & & \\
\hline t4t & 1 & . & [1] & 6 & Ti & 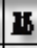 & $\mathbb{T}$ & I5 & 4 & 呾 & $\mathbf{3}$ & 0 & 1. & 9 언 & 미 \\
\hline Ints & & 1 & t2 & u & i & 굴 & III & 표 & 6 & $\pi$ & 111 & 1 & 5 & $\pi$ & T. \\
\hline 15 & & & 1 & IS & II & 4 & 79 & 푸 & 선 & (5) & T & $7 \pi$ & & 4 & 1 \\
\hline W & & & & 1 & $\boldsymbol{n}$ & $n$ & 표 & $\pi$ & 둔 & in & $\pi$ & 5 & 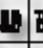 & 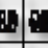 & 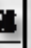 \\
\hline 1 & & & & & 1 & . & 풀 & I & D & 모 & as & $\pi$ & 15 & $i$ & 한 \\
\hline 니사. & & & & & & 1 & 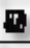 & 5 & 15 & 풀 & T & 13 & 1 & 5 & 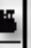 \\
\hline thl & & & & & & & 1 & D & D. & E.5. & is: & 䑤 & 85 & 87 & 3 \\
\hline 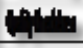 & & & & & & & & 1 & 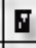 & in & 01 & $n$ & ㄴ) & 91 & 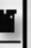 \\
\hline Lth & & & & & & & & & 1 & & 31 & 5 & 0 & 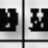 & 1 \\
\hline 㕸 & & & & & & & & & & 1 & bi. & $\mathbf{4}$ & $5 \pi$ & $\pi$ & 묘 \\
\hline$L_{4}$ & & & & & & & & & & & 1 & 01 & E: & 7 & $=$ \\
\hline 情亩 & & & & & & & & & & & & 11 & $\mathbb{3}$ & 12 & 3 \\
\hline A & & & & & & & & & & & & & 11 & 9 인 & 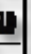 \\
\hline 落 & & & & & & & & & & & & & & 15 & 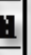 \\
\hline 幽 & & & & & & & & & & & & & & 1 & 1 \\
\hline
\end{tabular}

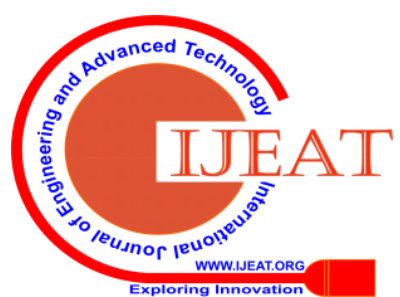


Table 16. From-To Time Table of Second Propose Layout

\begin{tabular}{|c|c|c|c|c|c|c|c|c|c|c|c|c|c|c|c|}
\hline \multicolumn{16}{|c|}{51} \\
\hline E & घ & d & $\mathbf{T}$ & 1 & $a$ & D & 9 & 6 & 1 & E & $\mathbf{n}$ & I & I & I & E \\
\hline & & & & & & & & & & & & & & & \\
\hline Hert & 1 & $\boldsymbol{1}$ & $\boldsymbol{E}$ & E: & 17 & 표 & 셔 & $m$ & 마 & 不 & $\mathbf{3}$ & 영 & 啠 & 도 & al \\
\hline 54 & & 1 & 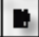 & 7 & 25 & 3 & 政 & $\mathbf{3}$ & 기 & 표 & 시 & M & $m$ & 문 & : \\
\hline ther & & & 1 & 翼 & $\boldsymbol{r}$ & 메 & 페 & 던 & 단 & I & 영 & 91. & E & $\therefore$ & 9. \\
\hline -4 & & & & 1 & 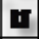 & I1 & is & I1 & gin & 노 & 구 & 5 & 11 & 주 & 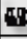 \\
\hline 15.7 & & & & & 1 & 드 & aㅔ & 4 & 대 & 1 & 15 & is & 5 & $\pi$ & 11 \\
\hline 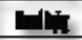 & & & & & & 1 & i & In & $m$ & 5 & in & $\boldsymbol{x}$ & ㅁ. & as: & 5 \\
\hline thellat & & & & & & & 1 & 5 & 9 & $\boldsymbol{T}$ & 져 & कis & 整 & $\boldsymbol{n}$ & $\boldsymbol{1}$ \\
\hline (1) & & & & & & & & 1 & 近 & 2 & 뎐 & 무․ & 표 & 지 & pris \\
\hline Lis & & & & & & & & & 1 & 교 & 71 & $m$ & Fi. & s & 吾 \\
\hline |x-4 & & & & & & & & & & 1 & $\mathbf{E}$ & a. & m & 표 & 떼 \\
\hline Lisit & & & & & & & & & & & 1 & EI & 5 & 문 & II \\
\hline 7 & & & & & & & & & & & & 1 & 盖 & i1 & 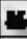 \\
\hline 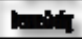 & & & & & & & & & & & & & 1 & 굴 & 수 \\
\hline 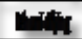 & & & & & & & & & & & & & & 1 & ia \\
\hline L & & & & & & & & & & & & & & & 1 \\
\hline
\end{tabular}

A spaghetti diagram was shown on Figure 11 to show the material and process flow of the product in the first new proposed layout. Conducting a From-To Chart to the Proposed Layout 2 as shown at Table 15 and Table 16. The total distance and time travelled of the current layout was being determined. Following the production flow of RMCT-T-CT-P-CV-MD-S-QC-MC1-MLS-MC2-LS-PC-DHPG the total travel distance is $132.24 \mathrm{~m}$ and the total travel time is $5.67 \mathrm{mins}$.

\section{F. Proposed Layout 3 for the Company}

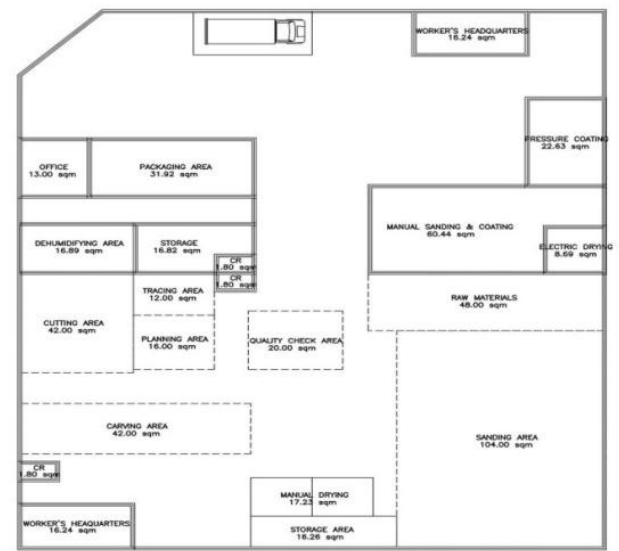

Figure12: Third Proposed Layout for the Company

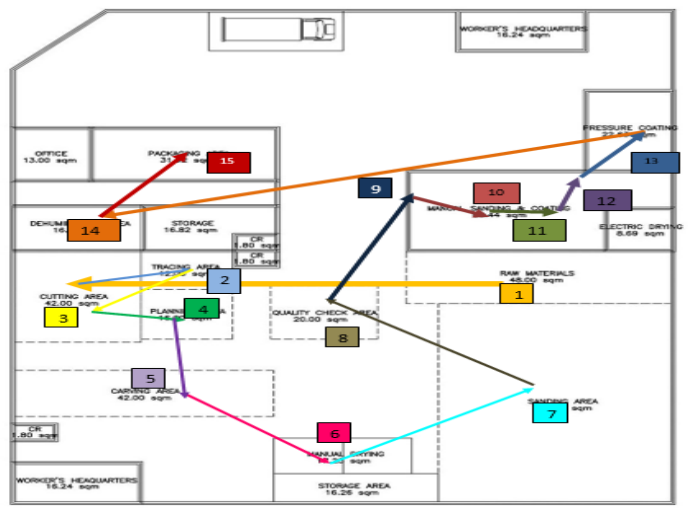

Figure 13. Spaghetti Diagram for the Third Proposed Layout for the Company
Table 17: From-To Distance Table of Third Propose Layout

\begin{tabular}{|c|c|c|c|c|c|c|c|c|c|c|c|c|c|c|c|}
\hline \\
\hline \multicolumn{16}{|c|}{ (1 } \\
\hline$\square$ & $\square$ & व & I & 1 & a & n & 5 & 5 & 1 & 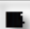 & 7 & 1 & E & 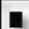 & I \\
\hline 口 & & & & & & & & & & & & & & & \\
\hline ו & 1 & : & n & E & ㅍ & 다 & c0 & Es & 夏 & I & I5 & 恶 & $\mathbf{n}$ & I5 & ins \\
\hline the & & 1 & 5. & SR & स & F & I3 & I & B & 8 & I & n & = & It & I \\
\hline Lt: & & & 1 & 进 & 요 & Et & ix & F & 무 & B. & n & ES & in & 피 & 무 \\
\hline דיטי & & & & 1 & स & D & ax & T & 目 & ? & In & I & $\pi$ & 표 & $\mathbf{m}$ \\
\hline 1י & & & & & 1 & 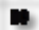 & $n$ & 뭉 & E & 풀 & II & ne & 35 & 표 & 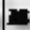 \\
\hline -1交 & & & & & & 1 & II & 5 & $n$ & III & $x$ & 15 & 119 & $\mathbf{m}$ & 㫮 \\
\hline לـ & & & & & & & 1 & 1 & E & 표 & a & In & 38 & in & In \\
\hline milne & & & & & & & & 1 & E & E & (19 & In & 18 & $\mathbf{a}$ & $\mathbf{a}$ \\
\hline Lly & & & & & & & & & 1 & is & B & 교 & Bd & Fin & ㄴ. \\
\hline -十 & & & & & & & & & & 1 & 58 & I & in & 盨 & $1 \pi$ \\
\hline why & & & & & & & & & & & 1 & $t$ & SI & II & E \\
\hline i & & & & & & & & & & & & 1 & ST & $\mathbf{n}$ & $n$ \\
\hline lit & & & & & & & & & & & & & 1 & 恐 & III \\
\hline 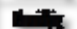 & & & & & & & & & & & & & & 1 & is \\
\hline 竞 & & & & & & & & & & & & & & & 1 \\
\hline
\end{tabular}

Table 18: From-To Time Table of Third Propose Layout

\begin{tabular}{|c|c|c|c|c|c|c|c|c|c|c|c|c|c|c|c|}
\hline \multicolumn{16}{|c|}{5} \\
\hline \multicolumn{16}{|c|}{7.} \\
\hline 口 & 口 & $\pi$ & $\mathbf{T}$ & 1 & $a$ & $\mathbf{n}$ & 1 & 6 & a & $E$ & 마 & I & $\mathbf{K}$ & 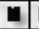 & 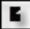 \\
\hline च & & & & & & & & & & & & & & & \\
\hline m & 1 & 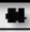 & ES & E & $\mathbf{E}$ & E & E & E & कis & 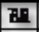 & 8 & A & 10 & 5 & \\
\hline - & & $t$ & 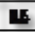 & 또 & 피 & E & 5 & 표 & $\mathbf{3}$ & 둔 & $\mathbf{n}$ & $\therefore$ & 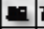 & (1) & B6 \\
\hline 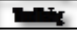 & & & 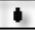 & 8 & III & $B$ & $\mathrm{n}$ & 표 & 15. & 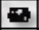 & 5 & ED & as: & mis & $\mathbf{F S}$ \\
\hline - -4 & & & & 1 & a & I & 5. & $\mathbf{E}$ & 3 & 15 & ma & $=8$ & m & 둥 & 8 \\
\hline thet & & & & & 1 & I & 典 & 5 & 需 & 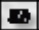 & a & 을 & na & 87 & 71 \\
\hline - & & & & & & 4 & II & if & -5 & 15 & $n$ & 8 & त्र & $\mathrm{As}$ & Ba \\
\hline maly & & & & & & & 1 & 돈 & 손 & 9 & 5 & 酸 & $=$ & 5 & An \\
\hline chith & & & & & & & & 1 & ens & 43 & 5 & 둘 & $m$ & an & 쬬 \\
\hline 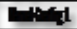 & & & & & & & & & 1 & int & in & $\mathbf{E}$ & in & 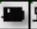 & 㘊 \\
\hline 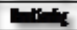 & & & & & & & & & & 1 & $\mathbf{5}$ & $\mathbf{I}$ & all & Ba & gूr \\
\hline -ing & & & & & & & & & & & 1 & Est & $\mathbf{5}$ & II & $n$ \\
\hline in & & & & & & & & & & & & 1 & 要 & 98 & 순 \\
\hline 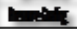 & & & & & & & & & & & & & 1 & Ba & n \\
\hline $4-\pi$ & & & & & & & & & & & & & & 1 & a \\
\hline & & & & & & & & & & & & & & & 10 \\
\hline
\end{tabular}

A spaghetti diagram was shown on Figure 13 to show the material and process flow of the product in the first new proposed layout. Conducting a From-To Chart to the Proposed Layout 3 as shown at Table 17 and Table 18. The total distance and time travelled of the current layout was being determined. Following the production flow of RMCT-T-CT-P-CV-MD-S-QC-MC1-MLS-MC2-LS-PC-DHPG the total travel distance is $109.67 \mathrm{~m}$ and the total travel time is $4.67 \mathrm{mins}$.

\section{G. Proposed Layout 4 for the Company}

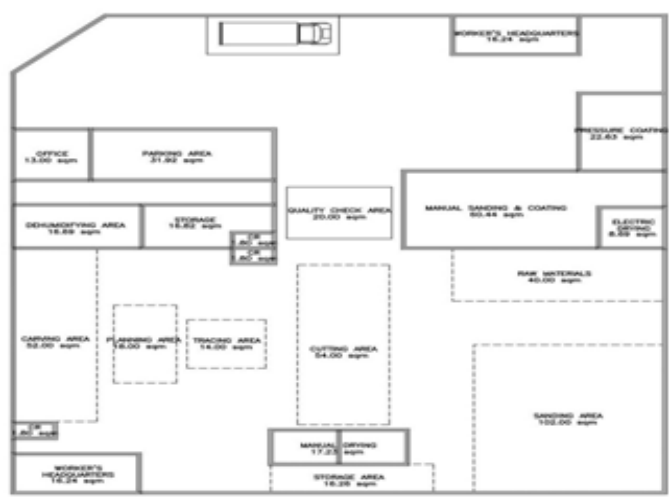

Figure14: Fourth Proposed Layout for the Company

Published By:

Blue Eyes Intelligence Engineering \& Sciences Publication

(C) Copyriaht: All riahts reserved.

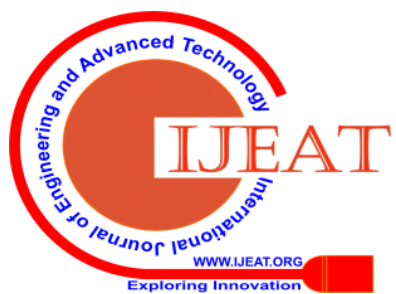


Productivity Improvement through the Systematic Application of Facility Layout Planning in a Small-Scale Woodcraft Manufacturing Industry

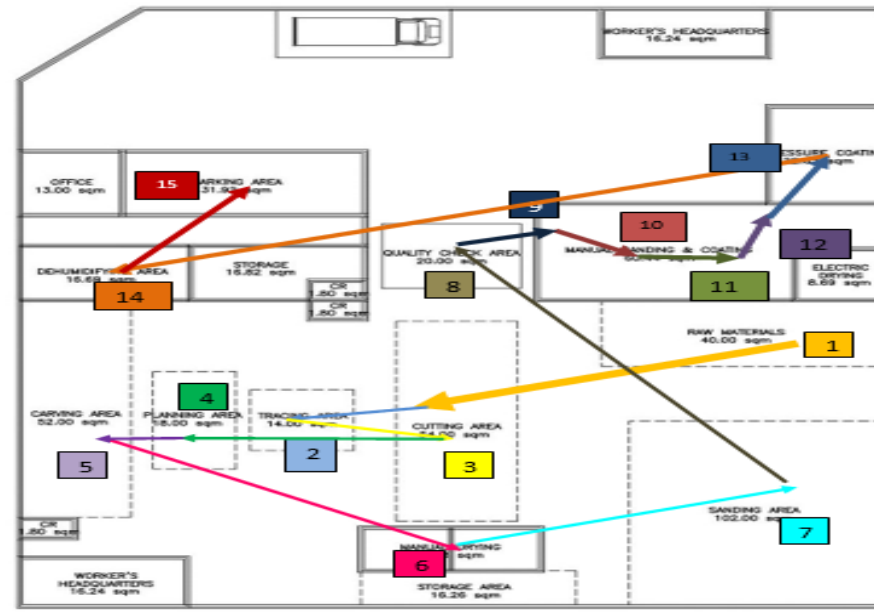

Figure 15: Spaghetti Diagram for the Fourth Proposed Layout for the Company

Table 19: From-To Distance Table of Fourth Propose Layout

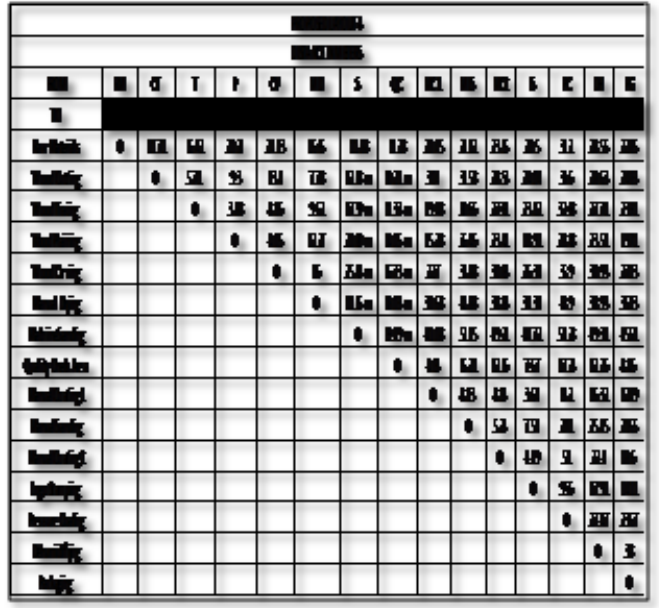

Table 20: From-To Time Table of Fourth Propose Layout

\begin{tabular}{|c|c|c|c|c|c|c|c|c|c|c|c|c|c|c|c|}
\hline \multicolumn{16}{|c|}{4} \\
\hline \\
\hline E & ㅁ & g & \begin{tabular}{|l} 
\\
\end{tabular} & I & $a$ & E & 1 & $\mathrm{C}$ & $\mathbf{m}$ & E & $\mathbf{m}$ & E & $\mathbf{E}$ & a & 5 \\
\hline 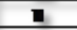 & & & & & & & & & & & & & & & \\
\hline 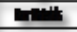 & - & 표프 & a & 표 & - & 8 & In & 10 & 젤 & 푸 & - & 궁 & s1 & 됴 & 힌 \\
\hline$-1+$ & & $\div$ & 5 & 표 & 15 & 표 & IIn & 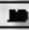 & In & 프 & $n$ & R & II & 표 & ت5 \\
\hline-1 & & & 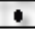 & II & ins & III & 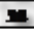 & 19 & $=8$ & 19 & $\mathbf{a}$ & -8 & 23 & $=$ & $\pi$ \\
\hline-11 & & & & 1 & 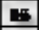 & 포 & $=$ & $=$ & $\mathbf{a}$ & 프 & -5 & gn & 15 & an & 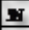 \\
\hline - & & & & & $\cdot$ & 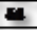 & int & II & 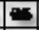 & II & \pm & $\mathbf{x}$ & (a) & $=0$ & 로 \\
\hline - 位 & & & & & & 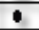 & III & \pm & 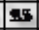 & 10 & E & 둔 & 国 & E & B \\
\hline 단 & & & & & & & $\bullet$ & $\mathbf{s i n}$ & 뭉 & 5 & 둔 & iㅇ & ax & ini & 185 \\
\hline Chith & & & & & & & & 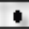 & $\mathbf{P A}$ & 6 & 조 & $=$ & 되 & 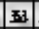 & 표 \\
\hline-14 & & & & & & & & & $\cdot$ & 11 & 些 & 8 & 0 & $\mathbf{a}$ & II \\
\hline 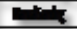 & & & & & & & & & & 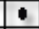 & $\mathbf{E}$ & $\mathbf{m}$ & $\pi$ & 제 & m \\
\hline-1 & & & & & & & & & . & & 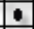 & B12 & 5 & 픈 & 됴 \\
\hline 1 & & & & & & & & & . & 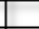 & &. & In & 푼 & $=$ \\
\hline-1 & & & & & & & & & . & - & & & 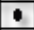 & $\mathbf{x}$ & - \\
\hline wk & & & & & & & 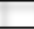 & & & & & & & $\cdot$ & 무 \\
\hline 上垃 & & & & & & & & & & & & & & & 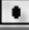 \\
\hline
\end{tabular}

A spaghetti diagram was shown on Figure 15 to show the material and process flow of the product in the first new proposed layout. Conducting a From-To Chart to the Proposed Layout 2 as shown at Table 19 and Table 20. The total distance and time travelled of the current layout was being determined. Following the production flow of RMCT-T-CT-P-CV-MD-S-QC-MC1-MLS-MC2-LS-PC-DH-

PG the total travel distance is $103.24 \mathrm{~m}$ and the total travel time is $3.87 \mathrm{mins}$.

Areas were being summarized as shown at Table 21. That came from the Block Diagrams.
Table 21: Block Diagram Areas Table

\begin{tabular}{|c|c|c|c|c|c|c|}
\hline Fores & Requined Nera & Curratlapou & Propsed lapout & hoposedlaput? & Aropsed lapos: & Propos lapouth \\
\hline WI & 1 & |ד, & 8 & $x$ & 4 & 5 \\
\hline$\measuredangle T$ & 8 & & 4 & 6 & 4 & 1 \\
\hline $\mathrm{T}$ & H & I & 1 & $\mathbf{1}$ & 1 & 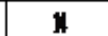 \\
\hline$P$ & 1 & $x$ & $y$ & 7 & 1 & 1 \\
\hline$\alpha$ & $y$ & q & 4 & $y$ & 1 & 1 \\
\hline 5 & 1 & 11 & m & 7 & 1 & 표 \\
\hline$\alpha$ & 1 & 8 & 8 & 1 & $\$$ & 8 \\
\hline
\end{tabular}

Table 22: Total Distance and Time Travel for Layouts

\begin{tabular}{|c|c|c|c|c|}
\hline Layout & $\begin{array}{c}\text { Distance } \\
\text { Travelled }\end{array}$ & $\begin{array}{c}\text { Time } \\
\text { Traveled }\end{array}$ & $\begin{array}{c}\text { Total } \\
\text { Distance } \\
\text { Travelled }\end{array}$ & $\begin{array}{c}\text { Total Time } \\
\text { Travelled }\end{array}$ \\
\hline Current & 142.15 & 6.92 & 1470.24 & 72.76 \\
\hline Proposed 1 & 114.9 & 5.23 & $1,321.02$ & 60.57 \\
\hline Proposed 2 & 132.24 & 5.67 & $1,427.96$ & 66.25 \\
\hline Proposed 3 & 113.76 & 5.08 & 1316.28 & 59.46 \\
\hline Proposed 4 & 104.06 & 4.97 & 1284.72 & 56.72 \\
\hline
\end{tabular}

Total Travel Distance and Time was being computed to determine the total distance and time flow using 408 units of round plates for a batch of production. Table 22 shows the summary of the computation. Frequency of travel was being used for the computation.

Table23: Productivity Computation

\begin{tabular}{|c|c|c|c|c|}
\hline Layout & $\begin{array}{c}\text { Standard } \\
\text { Process } \\
\text { Time }\end{array}$ & $\begin{array}{c}\text { Time } \\
\text { Travelled } \\
\text { (min) }\end{array}$ & $\begin{array}{c}\text { Total } \\
\text { Process } \\
\text { Time }\end{array}$ & $\begin{array}{c}\text { Units per } \\
\text { Day }\end{array}$ \\
\hline Current & 12.85 & 6.92 & 19.77 & 22.76 \\
\hline Proposed 1 & 12.85 & 5.23 & 18.08 & 24.88 \\
\hline Proposed 2 & 12.85 & 5.67 & 18.52 & 24.3 \\
\hline Proposed 3 & 12.85 & 5.08 & 17.93 & 25.1 \\
\hline Proposed 4 & 12.85 & 4.97 & 17.82 & 25.25 \\
\hline
\end{tabular}

Table 23 shows the productivity computation for each layout from the current to the proposed. Productivity was being computed using the 450 minutes of production time divided by the total process time per unit.

Proposal 1

Distance:

\%of Reduction $=(1470.24-1321.02) / 1470.24 \times 100=10.15 \%$

Time:

\%of Reduction $=(72.762-60.57) / 72.762 \times 100=16.76 \%$

Proposal 2

Distance:

\%of Reduction $=(1470.24-1427.96) / 1470.24 \times 100=2.88 \%$

Time:

\%of Reduction $=(72.762-66.25) / 72.762 \times 100=8.95 \%$

Proposal 3

Distance:

\%of Reduction $=(1470.24-1316.28) / 1470.24 \times 100=9.93 \%$

Time:

\%of Reduction $=(72.762-59.461) / 72.762 \times 100=18.28 \%$

Proposal 4

Distance:

\%of Reduction= $(1470.24-1284.73) / 1470.24 \times 100=12.61 \%$ Time:

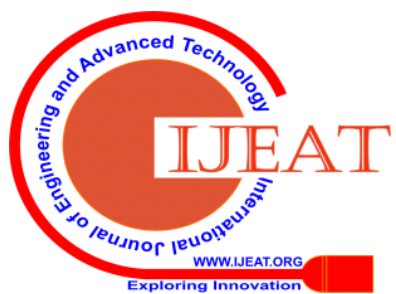


\%of Reduction $=(72.762-56.72) / 72.762 \times 100=22.05 \%$

For calculating the Percentage Reduction per Layout the following total distance and total time values shown on Table 22 was being used for the computation. Showing the results, Proposed Layout 4 which has a result of $12.61 \%$ reduction of distance and $22.05 \%$ reduction on time has the most reduced percentage of travel and distance time compared to the other layout alternatives.

\section{H. Cost Benefit Analysis}

Cost Benefit Analysis was being to compare and show the transparency of difference of the production between the alternative layouts. For computing the production cost the company could save the additional output per day was being computed. Additional outputs per day were being multiplied to the price of the product per unit. Cost Saved per day will be computed then. Table 24 shows the comparison between the costs saved per day per proposed layout.

Table24. Computation for Production Saving per Day

\begin{tabular}{|c|c|c|c|}
\hline Layout & $\begin{array}{c}\text { Additional Units } \\
\text { per Day }\end{array}$ & Cost per Unit & $\begin{array}{c}\text { Cost Saved per } \\
\text { day }\end{array}$ \\
\hline Proposed 1 & 2.12 & 135 & 286.36 \\
\hline Proposed 2 & 1.53 & 135 & 207.02 \\
\hline Proposed 3 & 2.34 & 135 & 315.34 \\
\hline Proposed 4 & 2.49 & 135 & 336.25 \\
\hline
\end{tabular}

\section{CONCLUSION}

Assessment of the current facility layout will improve the production process of the company that will reduce the travel time and distance. Four alternative layouts were being proposed for the company. Difference of each layout to their total travel distance and time was being computed to compare the layouts. Percentage reduction from current layout to the following proposed layout was also being computed. Resulting to, among the following proposed layouts the most reduced percentage of time and distance travelled is from the proposed layout 4 . With a result of $12.16 \%$ distance reduction and $22.05 \%$-time reduction. Cost Benefit Analysis was also being used for the comparison.

The fourth proposed layout still has the most saved cost per day of 336.25 pesos with additional output of 2.49 units. With these results it shows that it will be effective for the company to redesign and re layout the company. Doing this could help on the company's productivity and could bring an additional income for the company. Other proposed layouts could also be used but among the four alternatives. The fourth layout is he most beneficial.

\section{RECOMMENDATIONS}

The researcher advises to implement the Fourth Proposed Layout of the Company for their renovation. For this provides the highest decrease in time and distance traveled of their workers and also has the highest additional cost. The researcher would also like to introduce a Basic Safety Manual for the workers and the machines within the company premises. Based on observation, hazards are everywhere and could have a great impact in the company if not being solved as early as possible. An assessment to the company's facility was being conducted determining if it complies with the OSHA standards on illumination, ventilation and workplace temperature.
1. Beth811. (2009, November 12). Philippine Handicraft Industry: Their Benefits and Importance. Retrieved from https://hubpages.com/art/Philippine-Handicraft-IndustryTheir-

Benefits-and-Importance

2. Ghouse, Suhail. (2012). Indian Handicraft Industry: Problems and Strategies. International Journal of Management Research and Review. 2. 1183-1199.

3. Rutten, R. (1992). Provincial Entrepreneurs in Philippine Crafts. Retrieved

from http://philippinestudies.net/ojs/index.php/ps/article/viewFile/3520/61 24

4. Production Function and Production Management. (2015, March 23). Retrieved from https://www.ukessays.com/essays/business/theimportance-of-production-function-and-production-managementbusiness-essay.php

5. Monga, Varinder. (2015). Facility Layout Planning: A Review. International Journal of Innovative Research in Science, Engineering and Technology. 04. 976-980. 10.15680/IJIRSET.2015.0403027.

6. Syed Asad Ali Naqvi, Muhammad Fahad, Muhammad Atir, Muhammad Zubair \& Muhammad Musharaf Shehzad | Wenjun Xu (Reviewing Editor) (2016) Productivity improvement of a manufacturing facility using systematic layout planning, Cogent Engineering, 3:1, DOI: 10.1080/23311916.2016.1207296

7. Standardization of Work in a Manufacturing Industry. (2015, November8). Retrieved from https://irjet.net/archives/V2/i8/IRJETV2I8146.pdf

\section{AUTHORS PROFILE}

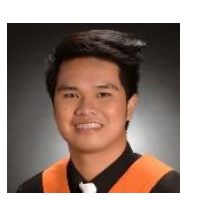

Ariel G. Cabildo. A graduate of B.S. in Mechanical Engineering from the Holy Angel University currently full time faculty member under the Mechanical Engineering Department of Holy Angel University. A licensed Mechanical Engineer and. currently enrolled at Nueva Ecija University of Science and Technology (NEUST) with a degree of Master of Engineering Management (MEnM). He is a regular member of the Philippine Society of Mechanical Engineers (PSME). He focuses in design and Fabrication Engineering, academicrelated and research-related subjects such as Automotive Engineering Design, Research, etc.

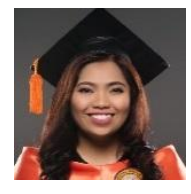

Ayezza Marie S. Figueroa. Production Engineer of SMK Electronics (Phils.) Corp. Studied at Holy Angel University With a degree of Industrial Engineering. Focuses in production and management such as process Engineering Design, Industrial Engineering Related, Research, etc.

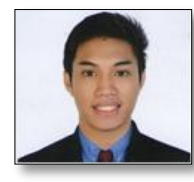

Emmanuel John V. Angeles. A graduate of B.S. in Mechanical Engineering from the Holy Angel University in 2013 and currently pursuing his Master of Engineering Management (MEnM) at Nueva Ecija University of Science and Technology (NEUST). He is a registered Mechanical Engineer duly licensed by the Professional Regulation Commission (PRC) of the Republic of the Philippines. currently the Secretary for the said organization of the Clark Chapter (Angeles City, Pampanga). He had 3 years of work experience as a production engineer for a Semi-Conductor Subsidiary company located in Clark (Angeles City, Pampanga), Philippines and currently works as a college instructor for Mechanical Engineering Department of Holy Angel University.

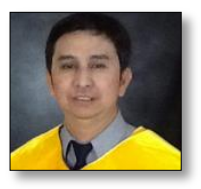

Jaypee B. Pajarillaga, a registered Mechanica Engineer with a masters and doctorate degree in Engineering Management. A graduate school professor in Engineering and full time Mechanical Engineering Faculty at Holy Angel University. He served as the Program Chairperson of the Department of Mechanical Engineering and Associate Dean of School of Engineering and Architecture. Dr. Pajarillaga is a researcher, he is the lead and co-researcher of different government funded research projects from DOSTDepartment of Science and Technology and CHEDCommission on Higher Education.

Published By:

Blue Eyes Intelligence Engineering

DOI: 10.35940/ijeat.D6793.049420

Journal Website: www.ijeat.org

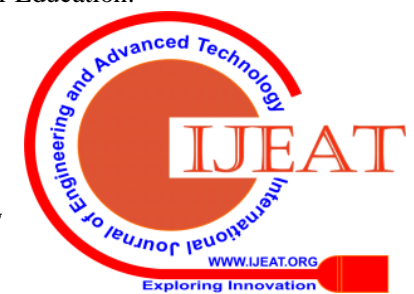


Productivity Improvement through the Systematic Application of Facility Layout Planning in a Small-Scale Woodcraft Manufacturing Industry

Lorinda E. Pascual, a Professor at the Electrical Engineering Department of the Nueva Ecija University of Science and Technology, a state university in Cabanatuan city Philippines. She holds Master's degree in Engineering Education major in Electrical Engineering and a Ph. D. in Mathematics Education.

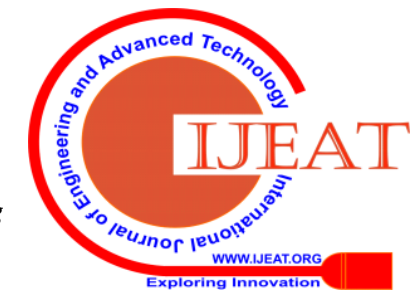

